\title{
FRAUDULENT FINANCIAL REPORTING AS A PERMANENT PROBLEM FOR DECISION MAKERS
}

\author{
Milorad Kovjanić, \\ PhD candidate, \\ Singidunum University, \\ Belgrade, Serbia
}

Correspondence:

Milorad Kovjanić

e-mail:

kovjanicmilorad64@gmail.com

\begin{abstract}
:
Manipulation of financial statements is a type of accounting fraud that is a permanent problem of companies observed at the global level.Losses due to fraud and manipulation of financial statements are huge and amount to more than 3.6 US dollars. This fact indicates the need for constant research on the types and methods of performing fraudulent activities as well as their causes, which is the topic of this paper. Therefore, the presented paper explores in a general sense the types and ways of fraudulent financial reporting, which is certainly a permanent problem of decision-makers.Certain directions for future research on the complex issue of fraudulent financial reporting have been identified.
\end{abstract}

\section{Keywords:}

financial statements, fraudulent actions, earnings management, decision making.

\section{INTRODUCTION}

Financial statements are important in meeting the function of accountability, and can be presented as a type of records that conveys the results of operating activities, i.e. financial performance of economic entities, and include a key, balance sheet, income statement and cash flow statement. Based on the information presented in these statements, various stakeholders make business decisions.In this regard, it is of particular importance that the financial information is valid. Among many other authors, Kedia and Philippon (2009) emphasize the importance of examining fraudulent/false financial reporting, given that the economic and social consequences of these events can be enormous. "Fraudulent financial reporting is nothing new, it is a phenomenon known for a long time in accounting practice" (Milojević et al., 2020, p. 262). Numerous non-financial frauds from the past have led to the loss of confidence of users of financial information in their credibility, and thus, necessarily, in increased caution in their use.Well-known world financial scandals point to this fact. As Mitrić et al. (2019, p. 43) points out, "the financial reporting system and the accounting and auditing profession have often been accused of fraud and loss of confidence in the reliability of financial information by numerous users and economic decision-makers". One of the common examples from the practice of manipulation is earnings management.The essence of this manipulation is to direct the profit in the direction of the desired outcome. Therefore, this example, as a representative example of manipulation, is specifically described in the paper.Defining fraudulent activities is a constant task of fraud researchers, given that the conditions in which business activities take place are constantly changing, and it is necessary to constantly upgrade these definitions. The paper provides an overview of several relevant definitions and perceptions of the concept of fraud. 
Fraud detection is not in the focus of external auditors, which is why the forensic option of auditing and accounting was created. The goal of forensic accounting and auditing is precisely to detect fraud with the aim of bringing the perpetrators of fraud to court on the basis of collected and court-accepted manner of collected and presented evidence.In addition to this goal, the preventive actions of these specific types of accountants and auditors with the aim of preventing fraud are on the same level. The result of such actions is the discovery of major world financial scandals, which is specially treated in the paper.

\section{DEFINITION OF FRAUDULENT ACTIONS AND EARNING MANAGEMENT}

Fraud is an action that is carried out with the intention of providing the perpetrator with an illegal benefit, and can occur in various areas (finance, investments, insurance, real estate), in different shapes and forms. Fraud is a complex concept, so different approaches to defining this concept stand out in the literature.It can be stated that fraud involves making a profit with the help of unauthorized actions, procedures and tricks, often include theft of resources, information and use of the property without approval.In principle, two views stand out, namely that manipulations are frauds if they contain certain elements that characterize frauds, but also that all manipulations are not illegal. Gulin (2002) points out that, although the term "manipulation" causes negative connotations associated with illegal activities, not all manipulations are, as a rule, illegal.In most cases, manipulations relate to activities and the effects of those activities that are within the law, as opposed to fraud in financial statements that explicitly include activities that are outside the legal norms (Gabrić and Miljko, 2018). In order for fraud to be seen in its entirety, it is necessary to start from the factors that influence its appearance.In this context, it is pointed out that the occurrence of fraud is influenced by external factors, such as economic, competitive, social, political, and internal factors, such as lack of controls or ineffective controls, lack of ethical standards, lack of positive business results, or profits, lack of trust, etc., and it is, therefore, necessary to perform a continuous risk assessment in order to establish a reliable sustainable fraud management system (Cvetković and Banović, 2019).

Manipulation of financial statements is a type of accounting fraud that is a permanent problem of companies observed globally. The losses due to the manipulation of financial reports are enormous.According to the ACFE (Association of Certified Fraud Examiners), these losses amount to more than 3.6 billion US dollars. Fraud is outside the Generally Accepted Accounting Principles (GAAP), while earnings management is within GAAP
(Erickson, Hanlon, \&Maidev, 2006), as underlined by Perols\&Lougee (2010). The situation is identical in the case of IFRS - International Financial Reporting Standards and International Accounting Standards - IAS.Earnings manipulation is one of the most common examples of manipulation and can be defined in different ways. Healy \& Wahlen (1999, p. 368) state that "Earnings management occurs when managers use judgment in financial reporting and in structuring transactions to alter financial reports to either mislead some stakeholders about the underlying economic performance of the company or to influence contractual outcomes that depend on reported accounting numbers ".Companies can manipulate financial statements in a variety of ways, and one that stands out "in particular" is earnings management by applying discretionary accruals or by committing fraud itself. Giorux (2003) defined earnings management as the use of operational and discretionary accounting methods to adjust earnings to the desired outcome. Ronen \&Varda (2008), point out that earnings management is actually intentionally changing financial information in order to give users of that information a wrong picture of the economic position of the company.Earnings management as a manipulation ultimately aims to mislead users of financial statements to the desired conclusion.

\section{THE ROLE OF AUDITORS AND FORENSIC ACCOUNTANTS IN FRAUD DETECTION AND MANAGERIAL RESPONSIBILITY}

It is a known fact that in an external audit, the auditor is required to determine that the financial statements do not contain materially inaccurate statements. The external auditor is not expected to detect fraud, but to determine the accuracy and truthfulness of positions in the financial statements. The task of the internal auditor is to determine fraud and manipulation, and the focus of the forensic auditor or accountant is to detect and prove fraud.However, although auditors are usually required to detect fraud in financial statements only if they have resulted in material misstatements (it can be formulated in this way), there are situations in which the auditor cannot be expected to identify fraud and situations in which the auditor should have identified fraud (Killen, 2016). Namely, in accordance with ISA 240, auditors are liable for fraud only if they have led to material misstatements (which he has disclosed or which he has not disclosed). Otherwise, the auditor is not liable for fraud that has occurred because it does not affect financial reporting.

In that sense, the possibility of performing two types of audits, auditing financial statements and auditing fraudulent activities, is emphasized. The audit of the financial statements alone does not reveal fraud. It is necessary to audit fraudulent activities. 
It is well known that generally speaking, there is no company that is immune to the risk of unethical behaviour or fraudulent activities, so the emphasis is on improving investor confidence and public confidence in financial statements. In this context, Petković et al. (2020) point out that there is often the question of where the line between legitimate and fraudulent earnings management is. The disclosed financial scandals have led to forensic accounting becoming an attractive opportunity for accountants in the fight against fraud. "Forensic accounting includes both litigation support and investigative accounting" (Milojević et al., 2020, p. 258). The world of forensic accounting has been evolving for the last 70 years. As already mentioned, some attribute the understanding of fraud as a subject of scientific study to the authors Edwin \& Cressey (1934), who published a paper entitled "Principles of Criminology", in which they defined and described the fraud triangle, which was later included in the Statements of Auditing Standards - SAS 99, Consideration of fraud in the audit of financial statements, which refers to the elements of the "triangle fraud". The fraud triangle framework, as one of the first models conceived on the basis of conducted empirical research, has been used to explain financial crime since the 1940s (Homer, 2019). As it turns out in theory, financial crime and fraud in the workplace only happen when the offender has enough opportunities, pressure and rationalization to commit a crime. As emphasized by Vukadinović, P. and Obradović, M. (2018), theoretical and empirical research has unequivocally shown the need to modify this model.

The task of a forensic auditor or forensic accountant is precisely to prove and detect fraud. Forensic accounting depends on different pillars. These pillars include the character of an accountant, the necessary experience and tools, and knowledge of the law (Hadman, 2018). In addition to activities to identify fraudulent activities, forensic accountants also work on their prevention. Various organizations and institutions, including, for example, the United Nations, as well as the World Bank, are increasingly directing their financial resources towards activities to strengthen the capacity of fraud investigators, on the one hand, and to raise awareness of the dangers posed by fraud to developing economies, on the other hand.

Management in organizations has a particularly important role in the fight against fraud. Fraud with financial reports does not take place in a vacuum, but it is made possible by the absence of an ethical culture (Mintz\& Morris, 2017). According to the same authors, the culture often created and a tone established at the top represent the image of a company willing to do whatever it takes to create a rosy image of financial results. Precisely because of this, one of the more important issues to consider is raising the awareness of management in the process of understanding the risk of fraud and the steps taken to mitigate the risk.
As stated by (Knežević et al., 2019), if we keep in mind that the company's management is responsible for the efficient operation of the company, preparation of financial statements, as well as for the functioning of internal control systems, it is logical to conclude that it has a dominant position in the company structure. As such (the management) possesses a unique ability to commit or approve fraud. This role of management is based on the position to directly or indirectly manipulate accounting records and present false information. For this reason, the auditor needs to pay special attention to management behaviour and performance in the business. In that sense, the great importance of internal control systems is pointed out as a proactive mechanism in preventing fraud in the financial and accounting segment, as well as in detecting warning signs, in order to reduce the inefficient use of company funds to the lowest possible level.

\section{SPECIFIC EXAMPLES OF FRAUD OCCURRENCE IN FINANCIAL STATEMENTS AND TOOLS FOR THEIR DETECTION}

The Association of Certified Fraud Examiners - ACFE is the world's largest anti-fraud organization and the leading organization for education and certification of antifraud training. In addition to strict accounting controls in the form of two dominant groups of accounting standards such as IFRS (International Financial Reporting Standards) and GAAP (Generally Accepted Accounting Principles), ACFE practice in the past has proved not so small number of abuses of "creative flexibility" and well-known financial scandals like Enron, Xerox or WorldCom in the United States, Toshiba in Japan or the Parmalat scandal in Italy, as well as the Agrokor case which is more famous regional scandal to us because it is in our neighbourhood, and this is exactly what they are proving.

In order to effectively manage the risk of fraud, it is necessary to know the techniques and ways of "styling" financial statements. All users of financial statements are interested in this information, both internal and external; banks, investors, business partners, financial institutions, control/inspection bodies, criminal inspectors, tax inspectors, internal and external auditors, controllers, etc.).The motive for the interest of these users of financial statements and especially control bodies is that such procedures are identified/recognized in the financial statements, with the aim of preventing and combating accounting manipulations (Cvetković and Bošković, 2018). In the relevant academic and professional literature, different approaches can be found in solving the problem of identifying fraudulent actions in financial statements, as well as different criteria for their division. One of the classifications of methods for detecting fraud in accordance 
with ACFE recommendations (Maedia, 2010), includes(1) horizontal and vertical analysis of financial statements, (2) analysis of financial indicators (ratio analysis), and especially trends in recent years, (3) application of the Beneish M-score test in identifying profit manipulations, (4), examination of statements according to Generally Accepted Accounting principles versus statements for tax purposes, as well as additional in the form of (5) irrational price/earnings: the benchmark is from 20 to 25 , and the average of the S\&P agency is approximately 36, (6) Application of SAS standard no. 99 by financial auditors and (7) other techniques. In addition to the above, it is important to keep in mind the application of Benford's law, i.e. Benford's distribution, which is often used in forensic proceedings and in some cases as the first step in the analysis of manipulations in financial statements. The Chartered Institute of Management Accountants (CIMA, 2008) suggested day-to-day techniques available to help identify irregularities that may be a fraud and investigate anomalies to decide whether further action should be taken:(a), reading history (publications - books and journals in the field of fraud and financial irregularities), (b) risk assessment of fraud, (c) benchmarking, (d) system analysis, (e) ratio analysis, (f) database modelling data, (g) specialized software, and (h) exception reporting.

In recent decades, a large number of corporate financial scandals have shaken many countries. One of those countries that have been affected to a large extent is the United States. Arthur Andersen - an auditing company (from the former "Big 5") did an external audit for both companies, which will be explained below. One example of this is the following case study. In a relatively short period of 15 years, Enron has risen from nothing to become the seventeenth-largest company in the United States and the most famous energy supplier in the world. However, during 2001-2002 it turned out to be one of the biggest corporate financial frauds. It was later determined that the company's financial statements were fraudulent i.e. false, as well as the fact that huge debts were hidden so that they were not visible on the company's accounts. One of the schemes they used was "inappropriate treatment of revenue". Namely, the chief financial officer of the company admitted in his presentation in court that most of the sales revenue was booked before the actual realization (Healy \& Palepu, 2003). During 1998, Enron increased its revenue from $\$ 20$ billion to \$ 31 billion, by the end of 1999 the increase in revenue went up to $\$ 40$ billion, and by the end of 2000 as much as $\$ 100$ billion, from which it can be concluded that there is a $390 \%$ increase in revenue over four years. One of the main reasons for the collapse of the Enron company is that the Securities and Exchange Commission allowed this company to use the market to market accounting method. Enron reported $\$ 1.4$ billion in pretax profit in 2002, then derivatives were manipulated, and the new report showed an increase from $\$ 1.8$ billion to $\$ 10.5$ billion, and the 2000 financial statements show over $\$ 16$ billion in profit on the basis of the derivative. (Li, 2010). As if the scandal with the company Enron was not enough to damage the identity of corporate America, another big financial scandal occurred, which seriously shook America. It is about the company WorldCom, which at that time was a telecommunications company that was one of the most influential in the world. However, the investigation conducted by the US Stock Market and Securities and Exchange Commission (SEC) in 2002 showed that the managers of that corporation increased the value of the company by as much as 11 billion dollars through various fraudulent actions. At the time of bankruptcy, WorldCom had a debt of about $\$ 32$ billion, and the value of its assets was at the level of \$ 107 billion (Jeter, 2003). This company presented all its expenses as CAPEX (capital expenditures, i.e. investments), which resulted in an unjustified increase in profits.

\section{CONCLUSION}

Research related to determining the quality of financial statements is always current and interesting, both to the scientific and professional public. Financial statements are used to make a number of economic decisions of interested recipients, and therefore it is of particular importance that the information they contain IS valid for business decision-making, both at the strategic and operational levels. Today, the profession of a forensic accountant is a fully formed profession that has developed as the business world has changed and progressed, both in the country and abroad. Forensic accounting is crucial and it is very important to help mitigate fraudulent actions in financial statements, and especially in exposing manipulations in earnings management. Further directions of research could go in the direction of raising the issue of licensing the profession of a forensic accountant in the Republic of Serbia, and the necessary measures to strengthen this profession through quality training. It also concludes that strong academic support would be needed to encourage the development of forensic accounting within the national framework. There is a significant number of tools that can be used to detect fraud. Some of them are Beneish's model, ratio analysis, Benford's law and other. A wellorganized system of internal control and internal audit in companies plays a major role in the adequate management of the risks of fraud. 


\section{LITERATURE}

ACFE: https://acfepublic.s3-us-west-2.amazonaws.com/2020Report-to-the-Nations.pdf.

CIMA (2008). Fraud risk management: A guide to good practice. The Chartered Institute of Management Accountants.

Cvetković, D., \&Banović, B. (2019, October, 18., 19.). Upravlja njerizicimaodprevarasaaspektaforenzičkogračunovodstva. Zbornikradovanaučnekonferencije: „Finansijskikriminalitet I korupcija", Institut za kriminološkaisociološkaistraživanja, Vršac, 243-258.

Cvetković, D., \&Bošković, V. (2018). Pojavnioblicikreativnograču novodstvainajčešćemanipulacije u finansijskimizveštajima. Oditor - časopis za Menadžment, finansijeipravo, Centar za ekonomskoifinansijskaistraživanja, Beograd, 2/2018, 78-89.

Erickson, M., Hanlon, M., \& Maydew, E. L. (2006). Is there a link between executive equity incentives and accounting fraud? Journal of Accounting Research, 44(1), 113-143.

Giroux, G.A. (2003). Financial analysis: a user approach. Wiley. New York.

Gulin, D. (2002). Manipulacije na financijskim tržištima i njihov utjecaj na financijske izvještaje. Računovodstvo, financije i revizija u suvremenim gospodarskim uvjetima, XXXVII. simpozij Pula, Zagreb: HZRiF.

Hadman, M.V. (2018).The Role of Forensic Accounting in Discovering Financial Fraud, International Journal of Accounting Research. (6)2, 1-6. doi:10.35248/2472114X.18.6.176

Healy, P. M., \&Wahlen, J. M. (1999). A review of the earnings management literature and its implications for standard setting. Accounting Horizons, 13(4), 365-383.

Healy, P. M. \& Palepu, K. G. (2003). The Fall of Enron. Journal of economic perspectives, 17(2), 3-26.

Homer, E.M. (2019). Testing the fraud triangle: a systematic review. Journal of Financial Crime, 172-187. 10.1108/ JFC-12-2018-0136.

Jeter, L.V. (2003). Disconnected: Deceit and Betrayal at Worldcom. John Wiley and Sons.

Kedia, S., \& Philippon, T. (2009). The Economics of Fraudulent Accounting. Review of Financial Studies, 22, 2169-2199.

Killen, L.K. (2016). Ratio of Income tax expense to Income from operations as an Indicator of Fraud. Dissertation Submitted to Northcentral University, Graduate Faculty of the School of Business and Technology.

Knežević, S., Mitrović, A., \&Cvetković, D. (2019). The role of auditing profession in detecting frauds in financial statements. NBP - Journal of Criminalistics and Law, 2(2), 97-109. doi: 10.5937/nabepo24-18979.

Li, Y. (2010). The Case Analysis of the Scandal of Enron. International Journal of Business and Management, 5(10), 37-41, DOI:10.5539/ijbm.v5n10p37.
Maedia, M. (2010). The Complete Guide to Spotting Accounting Fraud \& Cover-Ups: Everything You Need to Know Explained Simply. Atlantic Publishing Group, Inc.

Mitrić, M., Stanković, A., \&Lakićević, A. (2012). Forensic Accounting - the Missing Link in Education and Practice. Management - Journal for Theory and Practice Management, 65, 41-50.

Milojević, S., Paunović, J., Vuksanović, N. (2020). The role of accountants in litigation support and expert witnessing in the republic of Serbia. International Academic Conference „Education and Social Sciences Business and Economics“. International Academic Institute, Belgrade, Serbia, 2 March, 2020, Book of proceedings. ISBN: $978-$ 608-4881-08-7, pp. 255-260.

Milojević, S., Radojičić, Ž. \&Vujić, M. (2020). Key non-standardized financial metrics based on the income statement for measuring hotel performance. International Academic Conference „Education and Social Sciences Business and Economics". International Academic Institute. Belgrade, Serbia, 2 March, 2020, Book of proceedings. ISBN 978-608-4881-08-7, pp. 261-269.

Mintz, S.M. \& Morris, R.E. (2017). Ethical Obligations and Decision Making in Accounting, Text and Cases, Fourth Edition. McGraw-Hill Education, New York.

Perols, R.J. \&Lougee, B.A. (2011). The relation between earnings management and financial statement fraud. Advances in Accounting, 27(1), 39-53. https://doi.org/10.1016/j.adiac.2010.10.004.

Petković, Z., Odalović, T., Mandić, I., Miladinović, V., Lazović, K. (2020, March, 2). The growing importance of forensic accounting and accounting practice. „Education and Social Sciences Conference Business and Economics Conference". International Academic Institute, Belgrade Business and Arts Academy for Applied Studies Belgrade.

Ramos, M. (2003). Auditors' Responsibility for Fraud Detection. Journal of Accountancy, 99.

https://www.journalofaccountancy.com/issues/2003/jan/auditorsresponsibilityforfrauddetection.html.

Ronen, J. and Varda, Y. (2008), Earnings management: Emerging insights in theory, practice, and research, Springer, New York.

Sutherland, E.H. \&Cressey, D. R. (1992). Principles of Criminology. General Hall.

Vukadinović, P., \&Obradović, M. (2018). Teorijskiiempirijskiaspektitrouglaprevare, Revizor, 21 (81), 39-49. 